\title{
Diarrhoea of famine and malnutrition: investigations using a rat model. 1 Jejunal hypersecretion induced by starvation
}

\author{
A Young, R J Levin
}

Abstract

The effects of progressive starvation for up to three days on the secretory functions of the intestine were investigated using in vitro and in vivo preparations of rat jejunum and secretagogues whose action was either through cyclic AMP or $\mathrm{Ca}^{++}$. Initial starvation for $24 \mathrm{~h}$ (day 1) did not significantly alter the basal net electrogenic ion secretion measured in vitro as the short circuit current (Isc, $\mu \mathrm{amps} / \mathrm{cm}^{2}$ ) or the change in electrogenic ion secretion ( $\Delta$ Isc) induced by the secretagogues. By day 2 of starvation, however, the maximum $\Delta$ Isc transient induced by the cholinergic and other secretagogues $(\Delta$ Isc $=$ Isc $\max$ - basal Isc) was greatly increased (up to a maximum of $117 \%$ ) compared with the fed controls on an area basis. The $\Delta$ Isc were even greater on day 3 of starvation. If a tissue weight basis was used to normalise the data the increase became even more marked. The enhancement in secretion was not caused by a decrease in absorptive capacity as glucose, added mucosally, gave larger increases in absorptive currents in the starved than in the fed jejuna. Bethanecol dose- $\Delta$ Isc response curves in fed and starved jejuna showed an increase in the maximum electrogenic secretion in the starved but no apparent change in the affinity of their cholinergic receptors mediating the enhanced secretion. The starvation-induced increase in secretion elicited by bethanecol was blocked by atropine, indicating that the receptors were muscarinic, but was unaffected by tetrodotoxin indicating that the enteric neural innervation was not essential for its expression. Noradrenaline released by tyramine was greater in the starved than the fed jejunum, suggesting that a decreased sympathetic tone was unlikely to be the major cause of the starvation induced secretory enhancement. Measurement of jejunal fluid movements in vivo showed that in fed controls and throughout the three days of starvation there was an unchanged net fluid absorption in the basal, unstimulated state. By day 2 and day 3 of starvation, however, bethanecol stimulated fluid secretion was very much greater than that of the fed controls. This increase in fluid secretion was concomitant with significant increases in the concentration of chloride in the lumenal fluid. Starvation thus appears to make the rat jejunum hypersensitive to cholinergic and other secretagogues, increasing the electrogenic secretion of chloride in vitro and that of chloride and fluid in vivo. These results obtained with the rat model give a new insight into possible mechanisms by which the diarrhoea of human famine and malnutrition may be expressed.

Recurrent images of famine and malnutrition victims have become all too familiar but it is less well known that in adults and children intractable diarrhoea is usually the terminal condition. Although there have been many studies on the effects of starvation and undernutrition on the absorptive functions of the small intestine in animals ${ }^{1-5}$ and a few in man,,$^{6-8}$ no satisfactory explanation has been offered for this terminal diarrhoea seen in humans forced into starvation or severe undernutrition for extended periods. ${ }^{9-13}$ Moreover, even if the malnourished victims are refed orally, the diarrhoea can often become exacerbated after a few days remission and threaten life."1t While this diarrhoea of starvation and malnutrition has been known for millenia, ${ }^{9-13}$ few scientific investigations have been undertaken to characterise its cause. The diarrhoea is often attributed to bacterial infection but without adequate substantiation. Extensive bacteriological studies over the years, however, have indicated that only a relatively small percentage of the diarrhoea (about $15 \%$ ) is caused by bacteria. ${ }^{10-13}$ Helweg-Larsen et al ${ }^{11}$ described three types of diarrhoea associated with human starvation and severe malnutrition observed in concentration camps, namely a progressive, afebrile 'hunger diarrhoea', an 'infectious diarrhoea' and an 'alimentary diarrhoea' caused by sudden realimentation. The hunger diarrhoea was by far the most prevalent. Roediger ${ }^{13}$ suggested that the terminal diarrhoea of kwashiorkor and marasmus (corresponding to hunger diarrhoea) was the result of malnutrition of the enterocytes and colonocytes reducing their absorptive potential and capacity. Obvious ethical problems involved in controlled experiments with starving human victims has resulted in the intestine's secretory condition being practically ignored experimentally despite significant advances in our knowledge of the enterocyte's cellular mechanisms initially stimulated by work on cholera. ${ }^{15-17}$ Because of the lack of studies focused on the mechanism for the diarrhoea of starvation and malnutrition we have investigated the use of the rat as an experimental model. In this study, we have starved rats for up to three days and examined the effects on the secretory activity of the jejunum both in vitro and in vivo. Between 24 and 48 hours of starvation, the rat jejunum becomes hyper-reactive to a variety of stimuli that elicit intestinal secretion despite the decreasing cell population of crypts and villi. Most of the hypersensitivity appears to 
reside in the jejunal enterocyte at a postreceptor site or sites. Various aspects of the work have been communicated to the Physiological Society ${ }^{18-20}$ and the Nutrition Society. ${ }^{21}$

\section{Methods}

ANIMALS AND DIET

Male albino rats, weight $220-250 \mathrm{~g}$, of the Sheffield strain were allowed $a d l i b$ water and food (Diet CRM, Labsure, London). In the experimental groups water was given $a d$ lib but the diet was removed for periods of 24,48 , or 72 hours before the animals were used. The animals were housed routinely in plastic cages with raised wire mesh bottoms to reduce coprophagy. The lights were on from $530 \mathrm{am}$ until $630 \mathrm{pm}$ and the humidity $(72 \%)$ and temperature $\left(20(1)^{\circ} \mathrm{C}\right)$ were controlled.

\section{IN VITRO PREPARATIONS}

On the day of use the rats were anaesthetised with ip pentobarbitone sodium (Sagatal, May \& Baker; $60 \mathrm{mg} / \mathrm{kg}$ body weight). On achieving surgical anaesthesia, a midline incision was made and the midjejunum of the small intestine, some $30 \mathrm{~cm}$ from the ligament of Treitz, identified. A $5 \mathrm{~cm}$ length of this area was removed, cut open along its mesenteric border and mounted on pins as a flat sheet over an aperture (drilled in a plastic plate) of approximately $2 \mathrm{~cm}^{2}$. A second perforated plate was placed over this and the intestinal sheet clamped between two identical chambers (volume $10 \mathrm{ml}$ ) machined from perspex. The whole was immersed in a constant temperature water bath set at $38^{\circ} \mathrm{C}$. Each chamber was filled with $7 \mathrm{ml}$ bicarbonate saline buffer ${ }^{22}$ gassed with humidified $95 \% \mathrm{O}_{2}, 5 \% \mathrm{CO}_{2}$ at $38^{\circ} \mathrm{C}$. The tissue potential difference (pd in $\mathrm{mV}$ ), short circuit current (Isc in microamps) and resistance ( $R$ in ohms) were obtained by a previously published standard technique. ${ }^{24}$ The serosal fluid contained initially $10 \mathrm{mM}$ glucose and the mucosal $10 \mathrm{mM}$ mannitol (to maintain osmotic balance across the tissue). The mounted tissue was allowed to stabilise for 10 minutes before experiments were conducted. In a number of experiments the external smooth muscle of the intestine was removed. This was accomplished by placing the excised intact intestinal segment onto a glass rod and carefully cutting along the mesenteric border with a blunted scalpel blade. The smooth muscle layers could then be peeled away to leave a stripped segment. After use the tissue was removed and wet and dry weights measured.

In many of the early experiments the viability of the clamped tissue sheet was confirmed initially by adding $28 \mathrm{mM}$ glucose to the mucosal fluid. When the glucose transfer pd and Isc had reached its maximum maintained value (approximately five minutes after addition) the mucosal and serosal solutions were replaced with fresh buffer and the pd and Isc monitored until it restabilised. Electrogenic secretory activity was induced across the intestinal sheet by addition to the serosal solution of a variety of secretagogues. Three cholinergic secretagogues were used: (i) acetylcholine chloride; (ii) carbachol (carbamyl choline chloride) a more stable cholinergic agonist with both muscarinic and nicotinic actions; and (iii) bethanecol (carbamyl- $\beta$ methyl choline chloride) a stable, specific muscarinic agonist. In those experiments where theophylline was added to induce secretion the methylxanthine $(10 \mathrm{mM})$ was dissolved in a separate, warmed and gassed bicarbonate buffer solution which then replaced the normal mucosal and serosal buffers incubating the sheet (mucosal fluid $=10 \mathrm{mM}$ theophylline $+10 \mathrm{mM}$ mannitol, serosal fluid $=10 \mathrm{mM}$ theophylline $+10 \mathrm{mM}$ glucose). Other secretagogues used in the stripped preparation included prostaglandin $E_{2}(2 \cdot 8$ $\mu M), 5$ hydroxy-tryptamine $(50 \mu \mathrm{M}), \mathrm{A} 23187$ (5 $\mu \mathrm{M})$, forskolin $(10 \mu \mathrm{M})$, and dibutyryl cyclic AMP (1 mM). In some experiments either tetrodotoxin $(10 \mu \mathrm{M})$, atropine $(100 \mu \mathrm{M})$, or furosemide $(1 \mathrm{mM})$ were added to the serosal solution with the agonist acetylcholine $(1 \mathrm{mM})$.

The index of electrogenic secretory activity used was the maximum change in the Isc induced by the secretagogue ( $\Delta$ Isc). This was obtained by monitoring the Isc every 30 secs throughout the action of the secretagogue and then subtracting the basal Isc (usually that immediately before the addition of the agent) from the calculated induced peak of the current - namely, $\Delta$ Isc $=\max$ Isc-basal Isc. This Isc was then recalculated per $\mathrm{cm}^{2}$ serosal area of exposed tissue. In some cases the Isc was also calculated per $100 \mathrm{mg}$ per exposed tissue dry weight. Intestinal dry weights were obtained by cutting the chamber-exposed area of the mounted segment away from the rest of the tissue and drying overnight at $100^{\circ} \mathrm{C}$.

In experiments investigating the ion responsible for the secretory currents induced by secretagogue stimulation, the chloride ions in the bicarbonate saline ${ }^{22}$ were replaced with isoosmolar solutions of sodium, potassium, and calcium gluconate.

IN VITRO EXPERIMENTS INVOLVING TYRAMINE RELEASE OF ENDOGENOUS TISSUE NORADRENALINE

Tyramine releases noradrenaline from adrenergic nerves of the sub-mucosal plexus ${ }^{23}$ of isolated sheets of small intestine. ${ }^{24}$ In a series of experiments tryamine $(100 \mu \mathrm{M})$ was added to the solutions bathing sheets of jejuna from fed and three day starved rats in the presence of the monoamine oxidase inhibitor pargyline $(100 \mu \mathrm{M})$. The action of the locally released, endogenous noradrenaline was monitored by its depression on either the basal Isc or on the theophylline $(10 \mathrm{mM})$ stimulated Isc. Confirmation that tyramine was releasing noradrenaline was obtained by using the $\alpha_{2}$ blockers yohimbine $(10 \mu \mathrm{M})$ or idazoxan $(10 \mu \mathrm{M})$ to inhibit the action of the tyramine released active agent on the Isc.

IN VIVO MEASUREMENTS OF FLUID

Fluid movements were measured in vivo by using a modification of a technique published by Strombeck. ${ }^{25}$ The fed or starved rats were anaesthetised with ip pentobarbitone as described previously. When surgical anaesthesia 
was attained a midline incision was made and a $20 \mathrm{~cm}$ length of midjejunum cannulated using two glass cannulae. Debris in the lumen was washed out with warmed $0.9 \% \mathrm{NaCl}$. The saline was removed from the loop by blowing through the proximal cannula. The distal cannula was then removed and the incision tied off. Approximately $0.25-0.5 \mathrm{ml}$ of $0.9 \% \mathrm{NaCl}$ was instilled into the loop via the proximal cannula from a weighed, fluid filled syringe (A gm). The syringe was then reweighed (B gm) and the weight of fluid instilled, sufficient to just distend the loop, was calculated by difference (A-B gm). The animal was injected with ip bethanecol or carbachol ( 55 or $60 \mu \mathrm{g} / \mathrm{kg}$ body weight in $0.1 \mathrm{ml}$ $0.9 \% \mathrm{NaCl}$ respectively). The abdominal incision was closed with clamps, covered with $0.9 \% \mathrm{NaCl}$ moistened tissue and the animal placed on its side on a heated table for 20 minutes. At the end of the period the rat was killed by an incision into the thorax. The loop was excised, blotted free of excess fluid and weighed ( $\mathrm{C}$ gm). It was then cut open, drained, blotted and reweighed (D gm). The amount of fluid recovered was obtained by subtraction (C-D gm). The net movement of fluid into or from the loop was calculated as $[(C-D)-$ $(A-B)]$ gm. If absorption took place there was a net loss of fluid from the loop, $(A-B)>(C-D)$, and the sign of fluid movement is given as negative but if secretion occurred there was a net gain of fluid into the loop, $(C-D)>(A-B)$, and the sign of the fluid movement is given as positive. Control experiments were undertaken using an identical technique with similar volumes instilled into the $20 \mathrm{~cm}$ loops but instead of the ip injection of cholinergic secretagogue an equal volume of $0.9 \% \mathrm{NaCl}$ was used. The fluid movements in or out of the loop were calculated as $\mu \mathrm{g} / \mathrm{cm}$ jejunal length $/ \mathrm{min}$. As the specific density of the solutions weighed are all approximately equal to that of water, the error involved in regarding the weights of the fluid measured as being equal to the volumes secreted or absorbed are far less than other errors of the gravimetric technique. Thus the fluid weights can be assumed to be identical with fluid volumes.

In the initial study of fluid movements in vivo, ${ }^{19} 5 \mathrm{~cm}$ loops of jejunum were used. Their small size increased the handling, however, and the distension of the fluid-filled loop, both factors causing a basal secretory 'tone' in the loops instead of a normal absorptive 'tone'. Because of this effect the larger, $20 \mathrm{~cm}$ loops became the size of choice.

Measurements of chloride in the lumenal fluids were accomplished using a Buchler digital chloridometer (G D Searle \& Co, New Jersey, USA).

\section{MATERIALS}

All the chemicals were purchased from Sigma Chemical Company Ltd, Poole, England apart from the prostaglandin $E_{2}$ supplied by Upjohn Ltd, Crawley, England and the idazoxan ( $R x 781094 A)$ which was a gift from Reckitt and Colman, Hull, England.

\section{STATISTICAL ANALYSIS}

All results are shown as the mean (SE). Statistical comparisons were accomplished using Student's unpaired $t$ test with 0.05 as the level of significance. When multiple comparisons were needed the Kruskal-Wallis analysis of variance was used followed by Conover's multiple t-test to delineate specific differences. ${ }^{26}$

\section{Results}

EFFECTS OF STARVATION ON BODY WEIGHT AND VARIOUS JEJUNAL BIOELECTRIC PARAMETERS

The various changes that take place in the jejunum over the three day fast are shown in Table I. It is clear that for the first 24 hours (day 1) there are no significant changes apart from the small but significant $(\mathrm{p}<0.05) 8 \%$ decrease in body weight. After 48 hours (day 2) there are significant decreases in the body weight $(-12 \cdot 5 \%)$, in the wet and dry weight of jejunal tissue per $\mathrm{cm}^{2}(-11 \cdot 7 \%$ and $-13 \%$ respectively). While the basal Isc per unit area does not change, when placed per $100 \mathrm{mg}$ dry weight the basal Isc is very highly significantly greater than the fed control value $(+27 \%, \mathrm{p}<0 \cdot 001)$. After 72 hours of starvation (day 3 ) there is a very highly significant decrease in body weight $(-17 \%$, $\mathrm{p}<0.001$ ), in intestinal wet and dry weight per $\mathrm{cm}^{2}$ serosal area (both $-30 \%, \mathrm{p}<0.001$ ) and a small but significant decrease in intestinal resistance per $\mathrm{cm}^{2}(-11 \%, \mathrm{p}<0.01)$. As before, the basal Isc on a unit area basis in the $72 \mathrm{~h}$ starved rat is not significantly changed compared with the fed value but when calculated on a dry weight basis there is a highly significant $68 \%$ increase $(\mathrm{p}<0.01)$

\section{ELECTROGENIC SECRETORY RESPONSES} TO SECRETAGOGUES DURING PROGRESSIVE STARVATION FOR 72 HOURS The electrogenic secretory responses of unstrip-

TABLE I Various structural and bioelectric parameters of the jejunum in fed controls and during three days of progressive starvation. Results are given as the mean $(I S E), n$ is the number of animals used. The levels of the significance of the percentage changes from the fed control group are shown as the superscripts: a where $p<0.05, b$ where $p<0.01$, and $c$ where $p<0.001$

\begin{tabular}{|c|c|c|c|c|c|c|c|}
\hline & Fed controls & Starved day 1 & $\%$ change & Starved day 2 & $\%$ change & Starved day 3 & $\%$ change \\
\hline $\begin{array}{l}\text { n } \\
\text { Body wt }(\mathrm{g}) \\
\text { Jejunal wet wt }\left(\mathrm{mg} / \mathrm{cm}^{2}\right) \\
\text { Jejunal dry wt }\left(\mathrm{mg} / \mathrm{cm}^{2}\right) \\
\text { Resistance }\left(\mathrm{ohm} / \mathrm{cm}^{2}\right) \\
\text { Basal pd }(\mathrm{mv}) \\
\text { Basal Isc }\left(\mu \mathrm{A} / \mathrm{cm}^{2}\right) \\
\text { Basal Isc }(\mu \mathrm{A} / 100 \mathrm{mg}) \text { dry wt }\end{array}$ & $\begin{array}{l}30 \\
240(5) \\
103(3) \\
25(0 \cdot 7) \\
72(2) \\
6 \cdot 6(0 \cdot 2) \\
92(3) \\
377(14)\end{array}$ & $\begin{array}{l}18 \\
221(6) \\
100(2) \\
24(0 \cdot 7) \\
71(2) \\
6 \cdot 9(0 \cdot 2) \\
98(6) \\
408(21)\end{array}$ & $\begin{array}{l}-8^{\mathrm{a}} \\
-2 \cdot 9 \\
-4 \\
-1 \\
+4 \cdot 5 \\
+6 \\
+8\end{array}$ & $\begin{array}{l}18 \\
210(5) \\
91(4) \\
20(0 \cdot 9) \\
66(2) \\
5 \cdot 9(0 \cdot 3) \\
96(3) \\
480(13)\end{array}$ & $\begin{array}{c}-12 \cdot 5^{\mathrm{c}} \\
-11 \cdot 7^{\mathrm{a}} \\
-13^{\mathrm{c}} \\
-8 \\
-11 \\
+4 \\
+27^{\mathrm{c}}\end{array}$ & $\begin{array}{l}28 \\
199(5) \\
72(3) \\
16(0 \cdot 6) \\
64(2) \\
6 \cdot 4(0 \cdot 2) \\
101(4) \\
632(14)\end{array}$ & $\begin{array}{c}-17^{\mathrm{c}} \\
-30^{\mathrm{c}} \\
-30^{\mathrm{c}} \\
-11^{\mathrm{b}} \\
-3 \\
+10 \\
+68^{\mathrm{c}}\end{array}$ \\
\hline
\end{tabular}


TABLE II Electrogenic secretion ( $\Delta I s c)$ of unstripped jejuna removed from fed controls and rats starved for $24 h$ (day 1$), 48$ $h($ day 2$)$, and $72 h$ (day 3$)$. Responses were elicited by addition of carbachol (1 $\mathrm{mM})$, bethanecol $(1 \mathrm{mM})$, and theophylline $(10 \mathrm{mM})$ to the in vitro preparation. Results are shown as the mean $(S E)$. The number in square brackets represents the number of rats used. The levels of significance from the fed controls are shown as superscripts

\begin{tabular}{lccc}
\hline \multicolumn{4}{c}{$\Delta I s c\left(\mu a m p s / \mathrm{cm}^{2}\right)$} \\
\cline { 2 - 4 } & \multicolumn{1}{c}{ Carbachol } & \multicolumn{1}{c}{ Bethanecol } & Theophylline \\
\hline Fed controls & $52(9)[8]$ & $59(6)[12]$ & $61(6)[10]$ \\
Day 1 & $60(6)[8]$ & $55(7)[15]$ & $66(4)[9]$ \\
Day 2 & $85(9)[8]^{\star}$ & $83(7)[12]^{\star}$ & $97(4)[9] \dagger$ \\
Day 3 & $125(15)[8] \dagger$ & $103(6)[15] \dagger$ & $129(4)[8] \dagger$ \\
\hline
\end{tabular}

${ }^{\star} \mathrm{p}<0.01 ; \mathrm{tp}<0.001$.


Figure 1: Increase in Isc ( $\Delta$ Isc) induced across jejuna from fed, $24 h$ fasted (day 1$), 48 h$ fasted (day 2 ), and $72 h$ fasted rats by addition of $1 \mathrm{mM}$ carbachol to serosal solution. The $\Delta$ Isc is calculated on a unit serosal area basis (upper graph) and a $100 \mathrm{mg}$ dry weight basis (lower graph). Results are shown as mean ( $1 S E$ ) with the number of animals in brackets.



Figure 2: Time course of response of Isc to serosal addition of carbachol ( $1 \mathrm{mM})$ to jejuna from fed controls and $72 \mathrm{~h}$ starved rats. Results are plotted as mean $(S E)$ with the number of rats in brackets. ped jejuna calculated on a unit serosal area basis from fed rats and rats starved for 24, 48, and 72 hours using the secretagogues carbachol, bethanecol, and theophylline are shown in Table II. After 24 hours of food deprivation (day 1) the electrogenic secretory responses to the three secretagogues were not significantly different from those induced in the fed controls. After 48 hours of starvation (day 2), however, all the responses were significantly increased, for carbachol by $63.5 \%(\mathrm{p}<0.01)$, for bethanecol by $40.7 \%(\mathrm{p}<0.01)$ and for theophylline by $59 \%$ $(\mathrm{p}<0.001)$. Continuing the starvation period for 72 hours (day 3 ) increased further the amount of electrogenic secretion induced whether compared with the 48 hour starved values (carbachol $+42 \%, \mathrm{p}<0.05$; bethanecol $+51 \%$, $\mathrm{p}<0.01$; theophylline $+47 \%, \mathrm{p}<0.001)$ or to the fed controls (carbachol $+140 \%, \mathrm{p}<0.001$; bethanecol $+75 \%, \quad \mathrm{p}<0.001$; theophylline $+115.5 \%, \mathrm{p}<0.001)$. The basal Isc values of the jejunal segments from fed, day 1 , day 2 , and day 3 starved rats were not significantly different on the unit serosal area basis (Table I) but on a 100 mg dry weight basis those for days 2 and 3 become significantly increased from the fed controls. The data for the secretory responses induced by the secretagogues in Table II have not been listed on a $100 \mathrm{mg}$ dry weight but it is obvious that because of the decreases in jejunal dry weight (Table I), placing the electrogenic secretory responses to the secretagogues on this basis will exaggerate further the increases observed on a unit area basis for day 2 and 3 . This effect is shown clearly in Figure 1 using data for carbachol stimulated jejuna.

\section{TIME COURSES OF CHANGES IN ISC}

INDUCED BY SECRETAGOGUES

The time courses of the changes in the Isc in fed and $72 \mathrm{~h}$ starved jejuna (unstripped) are shown in Figures 2 and 3 for the serosal addition of $1 \mathrm{mM}$ carbachol (Fig 2) and $1 \mathrm{mM}$ bethanecol (Fig 3). The additions of $10 \mathrm{mM}$ theophylline to both mucosal and serosal solutions are shown in Figure 4. It is quite obvious from the time courses that all the secretagogues used induce a much greater secretory response, Isc, in the starved compared with the fed jejuna (see also Table II) but they also induce an increase in the total area under the time course graphs. This implies that not only is the maximum rate of secretion increased by starvation but so is the total amount of charge (ions) secreted.

In Figure 5 the responses of fed and starved jejuna to the addition of $28 \mathrm{mM}$ glucose to the mucosal bathing solution are shown. The 3 day starved jejuna responds with an $86 \%$ greater maximal increase (Isc fed $=35$ (5) $\mu \mathrm{amps} / \mathrm{cm}^{2}$ Isc starved $=65$ (7) $\left.\mu \mathrm{amps} / \mathrm{cm}^{2}, \mathrm{p}<0.01\right)$ ) and larger area (approximately $+78 \%$ ) under the time course curve indicating a greater hexose linked electrogenic absorption of ions by the starved compared to the fed jejuna.

DOSE RESPONSE CURVE TO BETHANECOL

In Figure 6 the Isc dose response to various doses of serosal bethanecol (from $1 \mu \mathrm{M}$ to $20 \mathrm{mM}$ ) are 


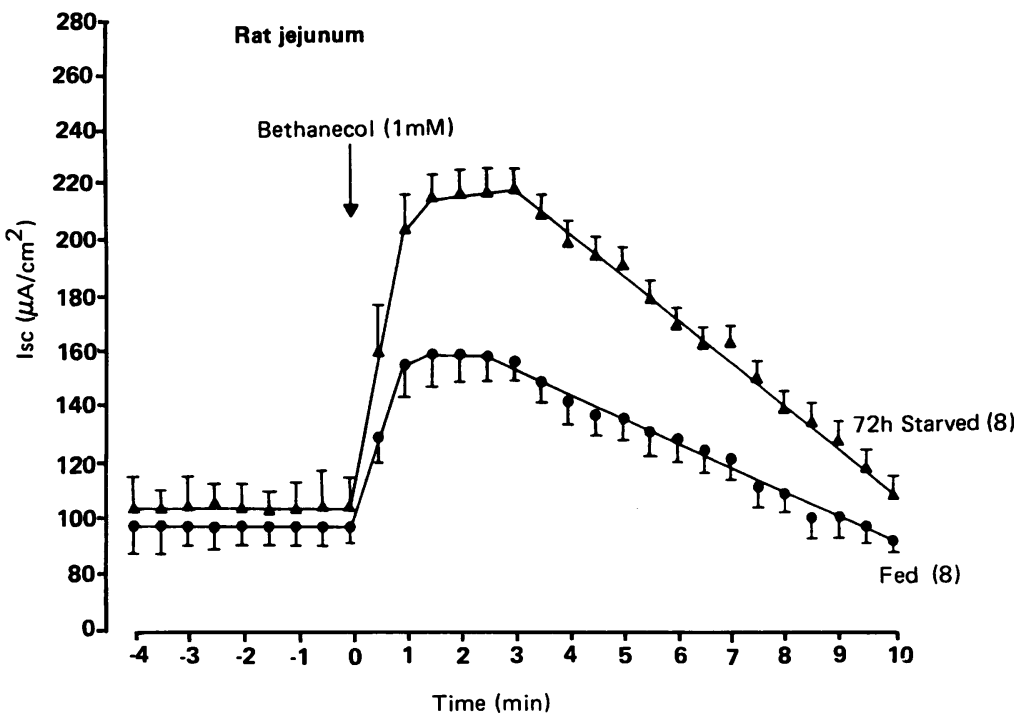

Figure 3: Time course of response of Isc to serosal addition of bethanecol ( $1 \mathrm{mM})$ to jejuna from fed controls and $72 \mathrm{~h}$ starved rats. Results are plotted as mean (SE) with the number of rats in brackets.

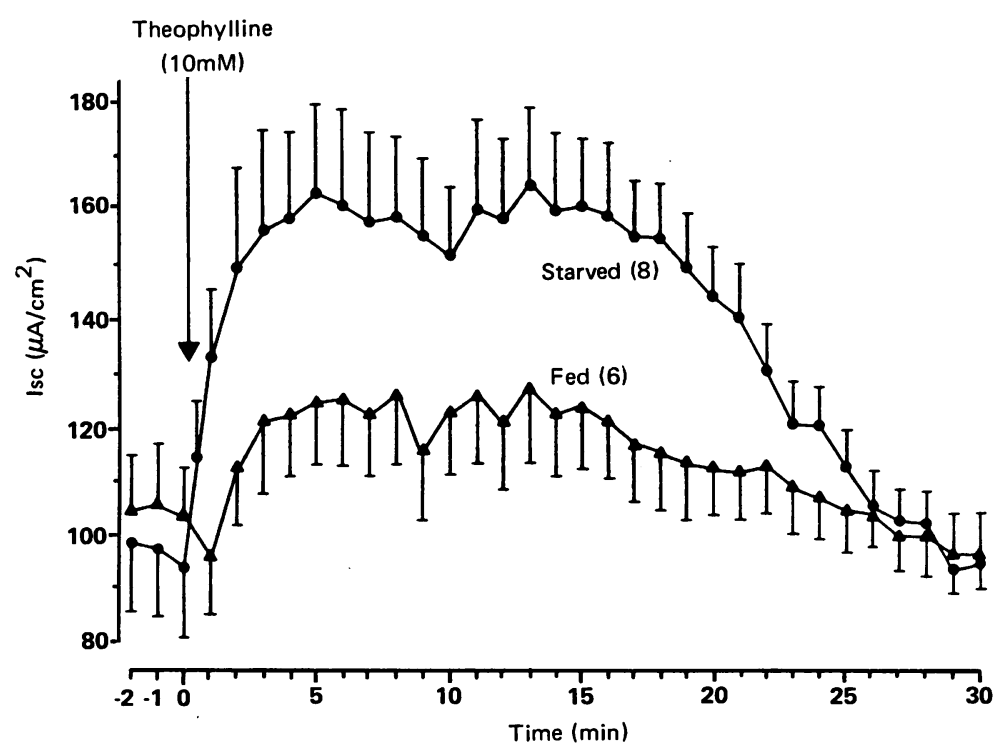

Figure 4: Time course of response of Isc to the mucosal and serosal addition of theophylline (10 $\mathrm{mM})$ to jejuna from fed controls and $72 \mathrm{~h}$ starved rats. Results are plotted as mean $(S E)$ with the number of rats in brackets.

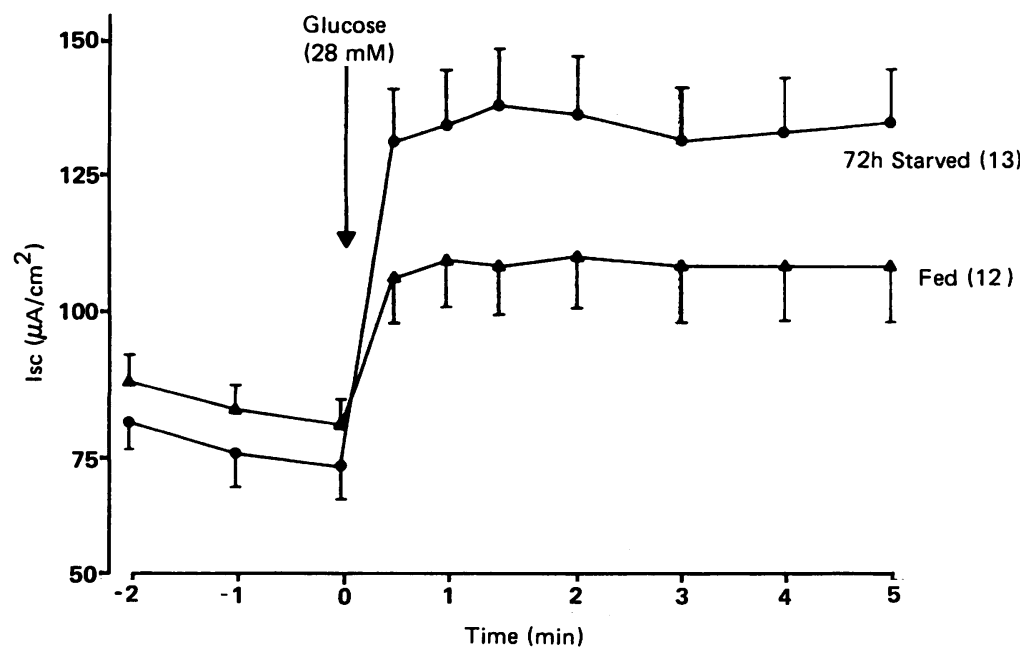

Figure 5: Time course of response of Isc to the mucosal addition of glucose (28 $\mathrm{mM})$ to jejuna from fed controls and $72 \mathrm{~h}$ starved rats. Results are plotted as mean $(S E)$ with the number of rats in brackets.

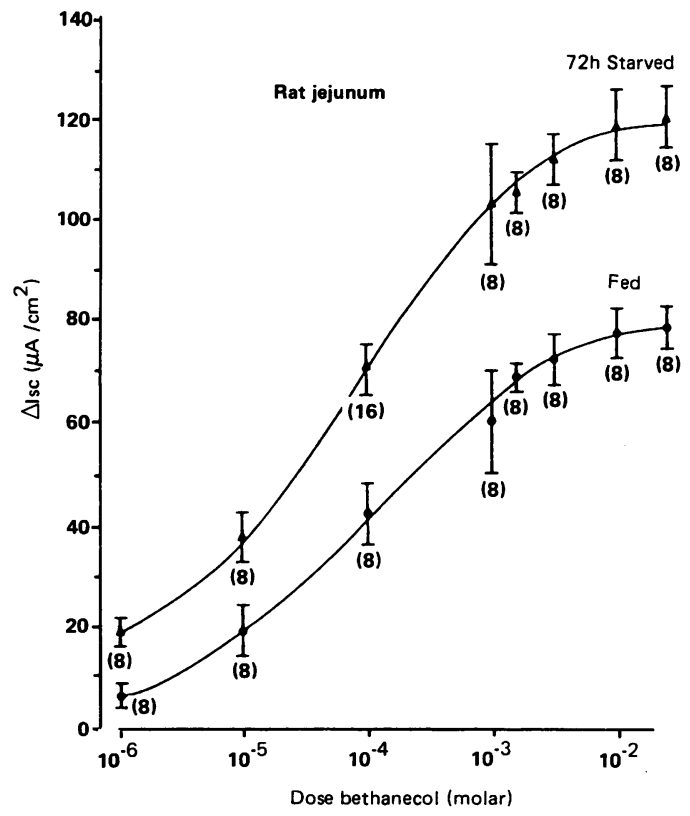

Figure 6: Response curves of jejunal $\Delta$ Isc against different doses of serosal bethanecol in fed controls and $72 \mathrm{~h}$ starved rats. Results are plotted as mean ( $S E)$ with the number of rats in brackets.

shown for the fed and $72 \mathrm{~h}$ starved unstripped jejuna. It is clear that the increase in electrogenic secretion in the $72 \mathrm{~h}$ starved jejunum is significantly greater over the fed for the whole range of bethanecol doses used. The data suggest an increase in the maximum secretory capacity of the starved gut rather than any significant change in the affinity that gives the $\mathrm{ED}_{50}$ dose (fed jejuna $=92 \mu \mathrm{mol}, 72 \mathrm{~h}$ starved jejuna $=64$ $\mu \mathrm{mol})$.

As bethanecol is known to be selective for muscarinic cholinergic receptor sites, the secretion induced by this agonist appears to be mediated via muscarinic rather than nicotinic receptors. The former are on enterocytes while the latter are in the enteric nervous network. ${ }^{16}$

\section{ACTION OF VARIOUS SECRETAGOGUES ON STRIPPED JEJUNA FROM FED AND 3 DAY STARVED RATS}

\section{Calcium mobilising secretagogues}

The stripped jejunal preparation facilitates the access of secretagogue to the basal membranes of the enterocytes and increases the concentration of the secretagogue in the biophase beneath the enterocytes. The preparation was used to examine the actions of a variety of secretagogues and secretory antagonists. Some secretagogues elicit secretion by mobilising and/or increasing the intracellular level of calcium. Included in this group are acetylcholine, the calcium ionophore A23187, and 5-hydroxytryptamine. The electrogenic secretion elicited by these agents are shown in Table III in jejuna from fed and 3 day starved rats. Acetylcholine induced an increased electrogenic response in starved jejuna of $115 \%$ $(p<0.001)$ compared with the fed controls, while A23187 induced an increase of $90 \%(p<0.01)$ and 5-hydroxytryptamine an increase of $84 \%$ $(\mathrm{p}<0.001)$. 
TABLE III Actions of secretagogues that elicit electrogenic secretion (measured as $\Delta I \mathrm{sc} / \mathrm{cm}^{2}$ ) through raised cytosolic calcium in stripped jejuna from fed control and three day starved rats. Results are shown as the mean $(S E)$ with the number of rats used in square brackets

\begin{tabular}{|c|c|c|c|c|}
\hline & \multicolumn{4}{|c|}{$\Delta I s c\left(\mu a m p s / c m^{2}\right)$} \\
\hline & Fed & 3 Day starved & $\%$ change & $p$ \\
\hline $\begin{array}{l}\text { Acetylcholine }(1 \mathrm{mM}) \\
\text { A23187 }(5 \mu \mathrm{M}) \\
\text { 5-Hydroxytryptamine }(50 \mu \mathrm{M})\end{array}$ & $\begin{array}{l}142(5)[15] \\
42(2)[8] \\
19(1)[15]\end{array}$ & $\begin{array}{l}305(15)[14] \\
80(3)[8] \\
35(2)[15]\end{array}$ & $\begin{array}{r}+115 \\
+90 \\
+84\end{array}$ & $\begin{array}{l}<0.001 \\
<0.01 \\
<0.001\end{array}$ \\
\hline
\end{tabular}

TABLE IV Actions of secretagogues that elicit electrogenic secretion (measured as $\Delta I s c$ ) through cyclic AMP in stripped jejuna from fed control and three day starved rats. Results are shown as the mean (SE) with the number of rats used in square brackets

\begin{tabular}{|c|c|c|c|c|}
\hline & \multicolumn{4}{|c|}{$\Delta I s c\left(\mu a m p s / c^{2}\right)$} \\
\hline & Fed & 3 Day starved & $\%$ change & $p$ \\
\hline $\begin{array}{l}\mathrm{PGE}_{2}(2 \cdot 8 \mu \mathrm{M}) \\
\text { Forskolin }(10 \mu \mathrm{M}) \\
\text { Theophylline }(10 \mathrm{mM}) \\
\text { Dibutyryl cyclic AMP }(1 \mathrm{mM})\end{array}$ & $\begin{array}{l}43(5)[7] \\
78(2)[8] \\
96(4)[8] \\
72(5)[19]\end{array}$ & $\begin{array}{l}76(5)[16] \\
122(7)[8] \\
208(3)[8] \\
116(5)[14]\end{array}$ & $\begin{array}{r}+77 \\
+56 \\
+117 \\
+61\end{array}$ & $\begin{array}{l}<0.01 \\
<0.01 \\
<0.001 \\
<0.001\end{array}$ \\
\hline
\end{tabular}
TABLE V Effects of replacing chloride ions by gluconate on
the basal Isc in jejuna (unstripped) from fed controls and three day starved rats. Results are shown as the mean $(S E)$.

Number in square brackets represents the number of animals

\begin{tabular}{|c|c|c|}
\hline & \multicolumn{2}{|c|}{ Basal Isc ( $\left.\mu a m p s / \mathrm{cm}^{2}\right)$} \\
\hline & Fed & 3 Day starved \\
\hline $\begin{array}{l}\text { Chloride present } \\
\text { Gluconate replacement of chloride }\end{array}$ & $\begin{array}{l}89(3)[10] \\
24(4)[16]\end{array}$ & $\begin{array}{l}93(3)[11] \\
36(3)[19]\end{array}$ \\
\hline
\end{tabular}

\section{Cyclic AMP stimulating secretagogues}

Another class of secretagogues elicits secretion by stimulating the production of cyclic AMP in the enterocyte. The effects of these agents on the electrogenic secretory responses in jejuna from fed and three day starved rats are shown in Table IV. Prostaglandin $\mathrm{E}_{2}$ increased the electrogenic secretory response in the 3 day starved jejuna by $77 \%(\mathrm{p}<0.01)$. Forskolin enhances the production of cyclic AMP by stimulating adenylate cyclase, it increased the electrogenic secretory response in the starved jejuna by $56 \%(\mathrm{p}<0.01)$. Theophylline increases the level of cyclic AMP in cells by inhibiting its breakdown by

\footnotetext{
Figure 7: Response of $\Delta I s c$ at different doses of serosal bethanecol in jejuna from fed control and $72 \mathrm{~h}$ fasted rats in the presence (solid line) and absence (dotted line) of chloride ions using gluconate as the replacement solute. Results are plotted as the mean $(S E)$ with number of rats in brackets.
}

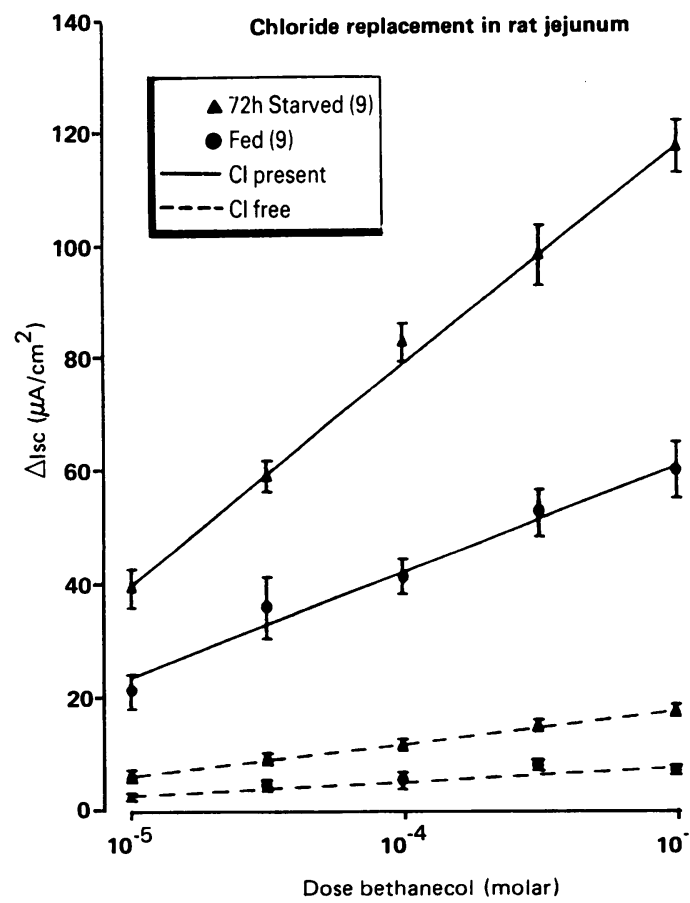

phosphodiesterase, it increased the electrogenic secretory response of the starved jejuna by $117 \%$ $(p<0.01)$. The direct addition of dibutyryl cyclic AMP to the starved jejuna induced a $61 \%$ increase in the secretory response $(p<0.001)$ compared to the fed jejuna.

\section{EFFECTS OF TOTAL REPLACEMENT OF}

CHLORIDE IONS ON BASAL AND

SECRETAGOGUE INDUCED CURRENTS

The effects of replacing all the chloride in the bathing buffers by gluconate on the basal Isc in the fed and starved jejuna (unstripped) are shown in Table $\mathrm{V}$ and on the secretory Isc induced by the serosal addition of bethanecol over the dose range $10^{-3}$ to $10^{-5} \mathrm{M}$ in Figure 7 . The basal Isc fell by $73 \%$ in the fed jejunum and by $61.3 \%$ in the starved jejunum (Table V). The basal Isc in the presence of chloride was not significantly different between the fed and starved segments $(p>0.05)$ but in the absence of chloride, the starved intestine had a significantly greater Isc $(+50 \%, \mathrm{p}<0.05)$ then the fed.

In the absence of chloride, the muscarinic agonist bethanecol caused only very small increases in the electrogenic secretion in the fed jejuna, the reductions in the secretory Isc's over the dose range used being in the range of 80 to $88 \%$. In the starved gut, the secretory Isc's were still extremely small, the decreases being in the range 85 to $86 \%$ compared with those in the presence of chloride, but they were significantly greater than those in the fed at each dose of bethanecol used $(p<0 \cdot 01)$. That the reductions in basal Isc (Table V) and Isc (Fig 7) in fed and starved jejunum were the result of chloride lack per se and not to non-specific secondary effects of the ion's absence was shown by the maintenance of normal Isc changes on the addition of mucosal glucose $(28 \mathrm{mM})$. In the fed jejunum, glucose when added to the mucosal fluid, caused an increase in the Isc of $39(4) \mu \mathrm{amps} / \mathrm{cm}^{2}(\mathrm{n}=10)$ in the presence and $33(3) \mu \mathrm{amps} / \mathrm{cm}^{2}(\mathrm{n}=9)$ in the absence of chloride. The values for the starved jejunum were 77 (3) $\mu \mathrm{amps} / \mathrm{cm}^{2}$ $(\mathrm{n}=11)$ in the presence and $69(6) \mu \mathrm{mps} / \mathrm{cm}^{2}$ $(n=9)$ in the absence of chloride. In both preparations the difference in current between the presence and absence of chloride ions was not statistically significant.

The results show that in both fed and starved intestine the basal current and the secretory currents induced by the cholinergic agonist are carried mainly by chloride ions to the mucosal fluid - that is, chloride secretion. Moreover, the increased secretory current of the starved intestine induced by the secretagogue is clearly carried mainly by the chloride ion. Further support for this conclusion is given in the next section with the use of furosemide, and inhibitor of chloride transport.

\section{ACTIONS OF VARIOUS ANTAGONISTS IN} STRIPPED JEJUNA

A number of antagonists were used to explore the characteristics of the electrogenic secretory currents induced by serosal acetylcholine in the stripped preparation (Table VI). Acetylcholine 
TABLE VI Actions of tetrodotoxin, furosemide, and of atropine on the electrogenic secretion induced by $1 \mathrm{mM}$ acetylcholine in stripped jejuna from fed control and three day starved rats. Results are shown as the mean $(S E)$ with the number of rats used in square brackets

\begin{tabular}{llcll}
\hline & \multicolumn{4}{l}{$\Delta$ Isc $\left(\mu \mathrm{amps} / \mathrm{cm}^{2}\right)$} \\
\cline { 2 - 5 } & Fed & 3 Day starved & $\%$ change & $p$ \\
\hline Acetylcholine & $142(5)[15]$ & $305(15)[14]$ & +115 & $<0.001$ \\
Acetylcholine+tetrodotoxin $(10 \mu \mathrm{M})$ & $151(12)[5]$ & $293(15)[6]$ & +94 & $<0.001$ \\
Acetylcholine+furosemide $(1 \mathrm{mM})$ & $24(2)[9]$ & $30(3)[10]$ & +25 & $\mathrm{NS}$ \\
Acetylcholine+ atropine $(100 \mu \mathrm{M})$ & $40(3)[8]$ & $50(4)[8]$ & +25 & $\mathrm{NS}$ \\
\hline
\end{tabular}

by itself induced a $115 \%$ increase in the Isc in the starved compared with the fed gut. Addition of $10 \mu \mathrm{M}$ tetrodotoxin had no significant effects on the secretory currents induced either in the fed or the starved segments (Table VI) showing that the acetylcholine is acting directly on the enterocytes rather than through the enteric nerve plexuses left in the stripped preparation. Evidence that the acetylcholine is acting on muscarinic rather than nicotinic sites is shown by the fact that $100 \mu \mathrm{M}$ atropine reduced the induced secretory currents in both fed $(-72 \%)$ and starved preparations $(-84 \%)$ to the same level.

Confirmation that chloride ion is involved in the secretory currents (see previous section on


Figure $8 a$ and $b$ : Time course of responses of basal Isc in fed jejuna (upper graph 8a) and $72 h$ starved jejuna (lower graph $8 b$ ). The solid circles show the changes occurring with the additions of saline controls followed by the addition of serosal bethanecol $(1 \mathrm{mM})$ while the open circles show the changes occurring with the addition of pargyline $(125 \mu M)$ followed by tyramine $(100$ $\mu M)$ and then serosal bethanecol. Results are plotted as mean $(S E)$ with the number of rats in brackets. chloride replacement experiments) induced by cholinergic stimulation is shown by serosal furosemide $(1 \mathrm{mM})$ reducing such currents in both fed and starved intestine to the same level, representing some 10 to $15 \%$ of the normal Isc (Table VI).

\section{TYRAMINE RELEASE OF ENDOGENOUS} NORADRENALINE

One possible factor involved in the hypersecretion exhibited by the jejuna from the 2 and 3 day starved rats could be changes in the level of the adrenergic sympathetic tone. As noradrenaline is known to inhibit intestinal secretory activity, decreases in its concentration in fasting intestine could allow a hypersecretory state. In order to assess the endogenous levels of noradrenaline, unstripped intestinal sheets from fed controls and the 3 day starved rats were treated with tyramine in the presence of the monoamine oxidase inhibitor pargyline using the procedure described by Tapper et al. ${ }^{2+}$ The tyramine releases noradrenaline from adrenergic nerve endings in the sheet which then inhibits any electrogenic secretory activity in both the basal and the stimulated state. Typical experiments are shown in Figures 8 and 9. A summary of the effects of the addition of pargyline and tyramine on the basal Isc of fed and 3 day starved jejuna are shown in Table VII. Both pargyline and tyramine caused decreases in the basal Isc which were always significantly greater in the starved tissue (Fig 8a, b) indicating that there was a greater amount of noradrenaline in the starved intestine. Bethanecol was added at the end of these experiments to confirm the viability of the preparations by the large increase in Isc due to the secretagogue's action on electrogenic secretion. Similar results were observed when pargyline and tyramine were added to fed and 3 day starved jejuna after stimulation with theophylline (Table VIII). The pargyline decrease, although greater in the starved than the fed, was not however significant but the tyramine effect was very much greater than that observed in the fed sheets (Fig 9a, b). The addition of serosal noradrenaline had a great inhibitory effect on the secretory Isc induced by theophylline in the fed and starved sheets which was reversed by yohimbine. Glucose $(10 \mathrm{mM})$ was added at the end of these experiments to confirm the viability of the preparations by the large increase in Isc due to the enhanced $\mathrm{Na}^{+}$ absorption linked to the hexose's transfer.

The conclusion from both sets of experiments was that there was very little 'tyramine releasable' endogenous noradrenaline in the intestine of fed rats but there was significant amounts in those from three day starved animals. If this increased noradrenaline in the starved intestine was reflected in an increased release then the intestine from these animals should actually display a reduced secretory activity rather than an enhanced one.

FLUID AND CHLORIDE MOVEMENT MEASURED IN VIVO

In order to confirm that the increase in electro- 
TABLE VII Basal Isc and changes in basal Isc ( $\Delta I s c)$ induced by addition of pargyline (125 $\mu M)$ and tyramine $(100 \mu M)$ to jejuna from fed controls and three day starved rats. Bethanecol ( $1 \mathrm{mM}$ ) was added finally to confirm the viability of the preparation. Results are shown as mean (SE). The negative values of the Isc indicate decreases in the basal Isc by the various agents while positive values indicate increases. The \% change column is a comparison of the changes induced in the starved animals with those of the fed. Number in square brackets represents number of animals used. See Figure 8 for time course protocol

\begin{tabular}{|c|c|c|c|c|}
\hline & \multicolumn{4}{|c|}{$I s c\left(\mu a m p s / c m^{\prime}\right)$} \\
\hline & Fed [9] & 3 Day starved [11] & $\%$ change & $p$ \\
\hline Basal & $89(6)$ & $88(8)$ & -1 & NS \\
\hline \multicolumn{5}{|c|}{$\Delta I s c\left(\mu a m p s / c^{2}\right)$} \\
\hline $\begin{array}{l}\text { Pargyline } \\
\text { Tyramine } \\
\text { Total (pargyline + tyramine) } \\
\text { Bethanecol }\end{array}$ & $\begin{array}{r}-10(2) \\
-7(1) \\
-17(2) \\
+50(3)\end{array}$ & $\begin{array}{l}-16(2) \\
-14(2) \\
-30(2) \\
+96(10)\end{array}$ & $\begin{array}{l}+60 \\
+100 \\
+76 \cdot 5 \\
+92 \%\end{array}$ & $\begin{array}{l}<0 \cdot 01 \\
<0.001 \\
<0 \cdot 001 \\
<0.001\end{array}$ \\
\hline
\end{tabular}

TABLE VIII Effect of addition of pargyline (125 $\mu M)$ tyramine $(100 \mu M)$ and adrenaline $(100 \mu M)$ on the $\triangle I s c$ induced by theophylline $(10 \mathrm{mM})$ in jejuna from fed controls and three day starved rats. Glucose $(28 \mathrm{mM})$ was added finally to confirm the viability of the preparation. The negative values of the Isc indicate decreases by the various agents while positive values indicate increases. The \% change column is a comparison of the changes induced in the starved animals with those of the fed. Results are given as the mean (SE). Number in square brackets represents the number of animals used. See Figure 9 for time course protocol

\begin{tabular}{lrlll}
\hline \multicolumn{5}{c}{$\Delta$ Isc $\left(\mu a m p s / \mathrm{cm}^{\prime}\right)$} \\
\cline { 2 - 5 } & Fed $[8]$ & 3 Day starved [II] & "ochange & $p$ \\
\hline Theophylline & $49(7)$ & $110(3)$ & +124 & $<0.001$ \\
Pargyline & $-11(3)$ & $-16(3)$ & $+45 \cdot 5$ & NS \\
Tyramine & $-5(2)$ & $-16(3)$ & +220 & $<0.01$ \\
Adrenaline & $-38(7)$ & $-77(10)$ & +103 & $<0.01$ \\
Glucose & $+39(3)$ & $+77(6)$ & $+97 \cdot 4$ & $<0.001$ \\
\hline
\end{tabular}

Figure $9(a)(b)$ : Typical time courses of responses of the

$\Delta I$ sc induced by the mucosal $(M)$ and serosal $(S)$ addition of theophylline $(10 \mathrm{mM})$ to the jejuna from fed controls (upper graph $9 a$ ) and $72 h$ starved rat (lower graph $9 b$ ) and the effects of serosal $125 \mu M$ pargyline (PAR), $100 \mu M$ tyramine (TYR), and $100 \mu M$ noradrenaline $(A D R)$. On addition of $n$-serosal yohimbine $(50$ $u M)$ the Isc was restored to the level obtained after pargyline. Washing out all the drugs caused the Isc to fall to a new slightly lower basal level. Addition of mucosal (m) glucose (10 $m M)$ induced large increases in the Isc confirming the viability of the preparations. Note the difference in scale of the Isc between the (upper) fed jejunum and the (lower) starved jejunum.

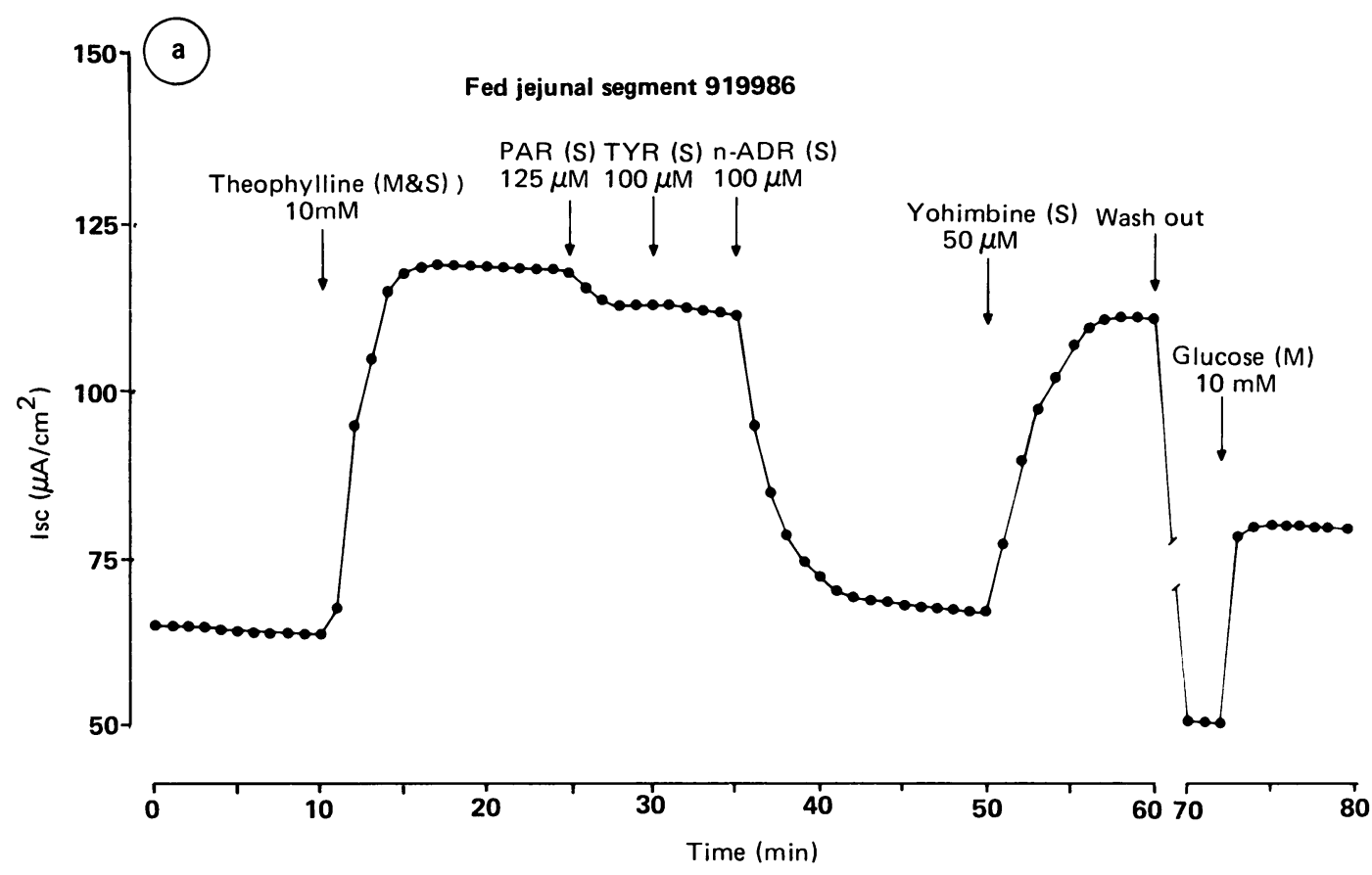

72h Starved jejunal segment 612986

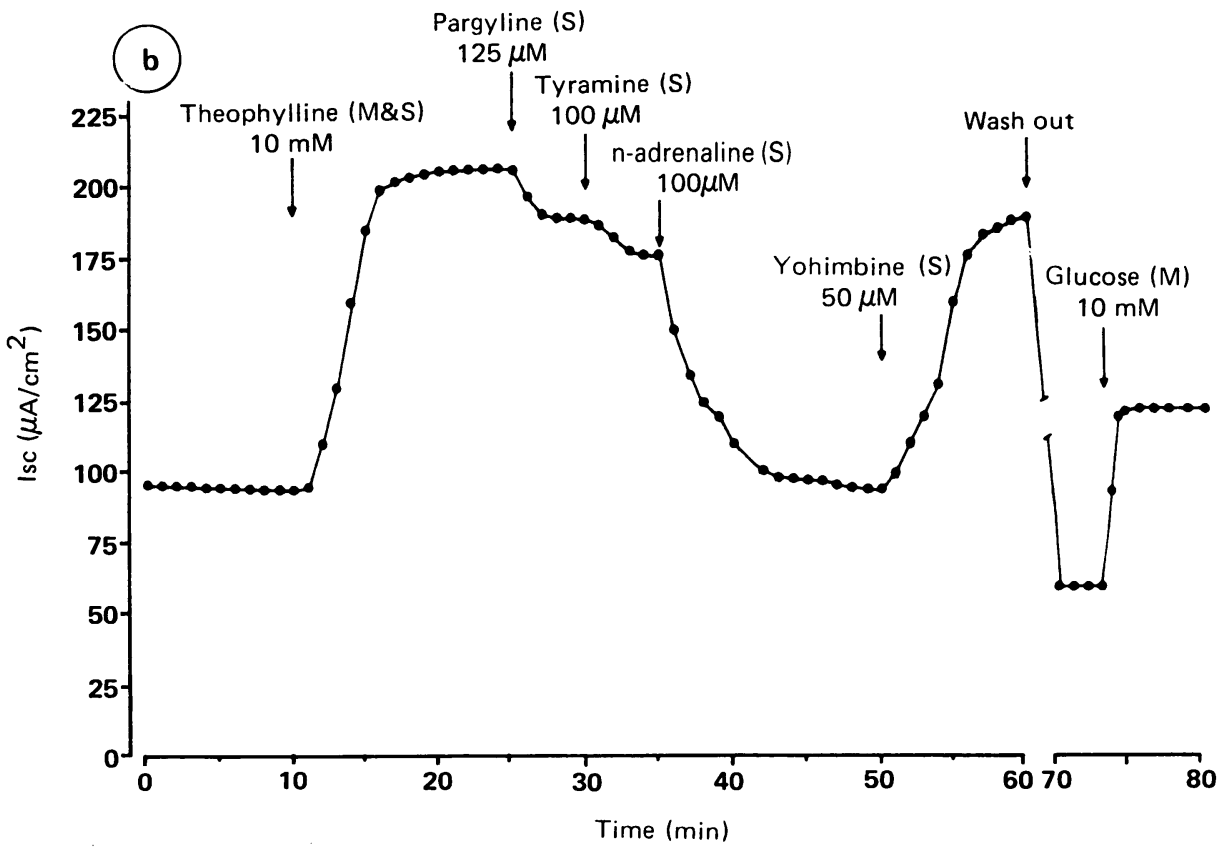


TABLE IX Basal and bethanecol induced fluid movement in jejuna from fed and day 1 to day 3 starved anaesthetised rats. Results are shown as the mean (ISE) with the number of animals used in square brackets. Net secretion (fluid movement to lumen) is given as positive while net absorption (fluid loss from lumen) is shown as negative. Bethanecol was given ip at a dose of 60 $\mu \mathrm{g} / \mathrm{kg}$ body wt and the fluid movements were measured over a 20 min period, but calculated for unit time. Statistical comparisons indicated by the superscripts use the Kruskal-Wallis ANOVA with specific differences delineated by Conover's $t$ tes

\begin{tabular}{lccc}
\hline & $\mu g$ fluid/min $/ \mathrm{cm}$ & \\
\cline { 2 - 4 } & Basal & Bethanecol stimulated & $\begin{array}{l}\text { \% change for bethanecol } \\
\text { stimulation }\end{array}$ \\
\hline Fed & $-907(41)[10]$ & $+873(31)[8]^{\mathrm{a}}$ & - \\
Day 1 & $-1031(30)[10]$ & $\begin{array}{c}+949(39)[8]^{\mathrm{b}} \\
+1976(27)[9]^{\mathrm{b}}\end{array}$ & $+8 \cdot 7(\mathrm{a} v \mathrm{~b}, \mathrm{NS})$ \\
Day 2 & $-871(21)[11]$ & $+2979(27)[10]^{\mathrm{d}}$ & $+126(\mathrm{a} v \mathrm{c}, \mathrm{p}<0 \cdot 01)$ \\
Day 3 & $-911(29)[13]$ & $+141(\mathrm{a} v \mathrm{~d}, \mathrm{p}<0 \cdot 001)$ \\
\hline
\end{tabular}

genic secretory activity in the starved jejuna was a valid index of fluid secretion by the jejuna, a series of experiments were undertaken to measure fluid movement to and from jejunal loops in anaesthetised fed controls and the progressively starved rats. The results are shown in Table IX. In the absence of any secretory stimulant the jejuna from both the fed controls and the starved rats displayed an absorptive tone which was not significantly different. Inducing secretion by ip bethanecol caused significantly greater amounts of fluid to be secreted into the lumen of the loops of the starved jejuna, on day $2(+126 \%, \mathrm{p}<0.001)$ and day $3(+241 \%$, $\mathrm{p}<0.001$ ). When carbachol (ip, $55 \mu \mathrm{g} / \mathrm{kg}$ body wt) was used to induce secretion in vivo on day 3 of starvation, fluid secretion was significantly increased by $144 \%$ (fed controls $450(50) \mu \mathrm{g} /$ $\mathrm{min} / \mathrm{cm} ; 3$ day starved $1100(110) \mu \mathrm{g} / \mathrm{cm} / \mathrm{min}$, $\mathrm{p}<0.001$ ).

The changes in the chloride concentration of the lumenal-instilled fluid in the basal and in the secretagogue stimulated state of the above experiments are shown in Table X. In the basal condition, both the fed and starved jejuna decreased the $\mathrm{Cl}^{-}$concentration of the lumenal fluid below that of the initial fluid, but the comparative changes between the jejuna were not significant. In the stimulated state, both cholinergic secretagogues caused a significant increase in the $\mathrm{Cl}^{-}$concentration of the lumenal fluid but those in the starved jejuna were significantly greater than those in the fed intestine (carbachol $+11.8 \%, \quad \mathrm{p}<0.001$, bethanecol $+8.5 \%, \mathrm{p}<0.01)$. The increased movement of fluid and of chloride into the lumen of the starved rat induced by secretagogues in vivo confirms that their action to increase the jejunal electrogenic secretion ( $\Delta$ Isc) monitored in vitro is a valid index of fluid secretion.

\section{Discussion}

The results show clearly that between $24-48$ hours of starvation the jejunum of the rat

TABLE X Changes in the chloride concentration (in $\mathrm{mM}$ ) of $0.9 \% \mathrm{NaCl}$ instilled into the lumen of control fed and three day starved rats in vivo in the basal state and after stimulation for $20 \mathrm{~min}$ with ip carbachol $(55 \mu \mathrm{g} / \mathrm{kg}$ body wt) or ip bethanecol $(60 \mu \mathrm{g} / \mathrm{kg}$ body wt). Results are shown as mean $(S E)$ with the number of animals used in square brackets

\begin{tabular}{lllcl}
\hline & Fed & 3 Day starved & $\%$ change & p \\
\hline Initial luminal fluid [9] & $151(4)$ & $151(4)$ & - & - \\
Basal [9] & $141(4)$ & $144(4)$ & +2 & NS \\
Carbachol [9] & $161(3)$ & $180(5)$ & $+11 \cdot 8$ & $<0 \cdot 001$ \\
Bethanecol [9] & $164(4)$ & $178(3)$ & +8.5 & $<0.01$ \\
\hline
\end{tabular}

exhibits a hypersensitivity to a variety of secretagogues that elicit electrogenic secretion in vitro. Increasing the duration of the starvation up to 72 hours increases the amount of secretagogue elicited electrogenic secretion. The increase is present even on a unit serosal area basis despite a decreasing population of enterocytes in the crypts and villi. ${ }^{27-29}$ Clearly, the increased secretion cannot be ascribed to a starvation induced reduction in the number of enterocytes. Indeed, if the secretagogue stimulated electrogenic secretion is calculated on a basis of $100 \mathrm{mg}$ jejunal dry weight, the increase in secretion in the starved jejunum compared with the fed controls becomes even greater. Furthermore, on a dry weight basis, even the basal Isc (electrogenic ion movement) across the jejuna (which is mainly electrogenic chloride secretion) is greater than in that of the fed on day 2 and 3 of starvation. This is not seen if the basal Isc is placed on a unit serosal area basis. Our data thus indicate that either the individual enterocytes of the starved jejuna on day 2 and 3 are more effective in secreting ions than individual fed enterocytes and/or a greater number of the enterocytes present are capable of secreting compared with those in the fed state. Starvation is known to reduce the mitosis in the crypts and to slow down the replenishment of enterocytes onto the villi, disturbing the normal balance of enterocytes on the villus. ${ }^{27.29}$ Thus in the starved state, the cells on the villus will tend to be more mature than in the fed. In general, ageing of the enterocyte on the villus appears to be linked with the maturation of its absorptive or transfer capacity rather than its secretive one. ${ }^{30}$ Moreover, starvation for 72 hours in rats has been shown to induce an increased zone of valine absorption as measured from the villous tip. In fed rats, valine absorption is detected at 160 microns while in the starved, it is seen at 200 microns. ${ }^{31}$ This greater absorptive capacity of the starved intestine is also reflected in our results with glucose. The addition of glucose causes a much greater increase in the absorptive Isc in the starved jejunum than in the fed confirming results obtained many years ago. ${ }^{+}$Our results, together with those of Thompson and Debnam, ${ }^{31}$ suggest that starvation induces in enterocytes both a greater absorptive and secretive function compared to the fed state. At present we cannot state definitively whether this action of starvation in slowing cell replenishment and increasing the age of the resident enterocytes is a direct cause of our hypersecretory sensitivity, but it certainly has to be taken into account in any final analysis of mechanisms to explain the hypersecretion of progressive starvation.

The hypersecretory behaviour of the starved jejunum is elicited by the two major groups of secretagogues: those that reputedly act by raising the level of intracellular calcium in the enterocyte (this group includes acetylcholine, the stable cholinergic agonists carbachol and bethanecol, 5-hydroxytryptamine and the calcium ionophore A23187) ${ }^{15163234}$ and those that act by increasing its intracellular concentration of cyclic AMP (this group includes prostaglandin E2, forskolin and theophylline, agents that activate and inhibit respectively the enzymes 
that are involved in the formation (adenyl cyclase) and the breakdown (phosphodiesterase) of the cellular cyclic AMP, and dibutyryl cyclic AMP itself). ${ }^{15} 16^{34}$ Do these findings tell us anything about the locus of the hypersecretory phenomenon? The cholinergic secretagogues presumably activate the hypersecretion through their binding to the muscarinic receptor on the serosal membrane of the enterocytes ${ }^{35}$ as the experiments with tetrodotoxin (a toxin that blocks neural transmission) and with atropine (a specific blocker of the muscarinic receptor sites) clearly showed that exogenous acetylcholine stimulated electrogenic secretion in the isolated jejuna by a direct action on the enterocyte and not through the enteric plexus in the wall of the preparation. As the calcium ionophore A23187 also elicits the hypersecretion in starved jejuna, however, this suggests that the response does not reside directly in the activation of the muscarinic receptor site but in processes that occur after namely, whatever intracellular mechanism(s) the rise in the enterocyte's intracellular $\mathrm{Ca}^{++}$ activates. Two studies published in abstract form have suggested that in rabbit ilea A23187 may cause prostaglandin release, ${ }^{36}{ }^{37}$ but this has not yet been investigated in rat intestine. It is thus possible that the $\mathrm{A} 23187$ induced secretion may be activated by a direct action of the ionophore on the enterocyte and an indirect one through prostaglandin stimulation. The results obtained with the second group of secretory stimulants, those whose action are mediated through cyclic AMP, indicate that the hypersecretory phenomenon of the starved jejuna can also be elicited by raising the cyclic AMP concentrations of the starved enterocyte. As this can be accomplished by the direct application of dibutyryl cyclic AMP, the increased cellular production of cyclic AMP is not the essential requirement for the secretory enhancement to be manifest. One locus for the hypersecretion thus appears to be after the cellular production of cyclic AMP and after the release of the intracellular calcium. At present, our experiments do not allow us to define the position of this locus in the enterocyte with any finer focus. We hope to undertake further experiments to delineate, with greater precision, the cellular mechanism(s) by which the electrogenic secretion is so dramatically enhanced by food withdrawal.

The results obtained with the ion replacement experiments and with furosemide reveal that the increase in secretagogue stimulated Isc observed in the starved jejunum is practically all carried by the chloride ion, indicating that it is mainly chloride secretion. Interestingly, when the basal Isc of the starved jejunum was compared with the fed in the absence of chloride ions, that of the starved was significantly greater, suggesting that in the basal state ions other than chloride could become involved in the excess secretion.

The correspondence between the development of the increased electrogenic secretion in vitro and the increase in fluid secretion in vivo over the starvation period suggest strongly that the two measures are characterising the same phenomenon of the hypersecretion. The increase in fluid in vivo was not caused by any decrease in the absorption tone of the jejunum because in the absence of any injected secretagogue the absorption of fluid from both fed and starved jejuna were not significantly different. Thus in the rat jejunum, measures of the changes in Isc induced by a variety of secretagogues appear to be a valid index of fluid and chloride secretion in vivo.

Starvation decreases the turnover of noradrenaline in rats. ${ }^{38}$ As noradrenaline is known to reduce intestinal secretory activity ${ }^{178-40}$ it was possible that the hypersecretory response of the starved jejunum could have been partly a product of a reduction in the normal, basal sympathetic 'tone' of the enteric innervation. The experiments to ascertain whether the hypersecretory responses of the starved jejuna could be ascribed to such a decreased sympathetic tone showed that the amount of 'tyramine-releasable' adrenergic transmitter was obviously greater in the preparations of starved jejuna than in those from the fed controls suggesting an increased sympathetic tone. In this sense, it is clear that the hypersecretion could not be a direct result of the decrease in adrenergic stores in the nerve terminals of the starved gut. It must be admitted, however, that it could be argued that the greater amount of noradrenergic transmitter found in the wall of the starved jejuna was present perhaps because it is not as easily released from its nerve terminals. More experiments are needed to better resolve the phenomenon.

An obvious question arises from our choice of the rat as a model for studying the diarrhoea of famine and malnutrition - namely, does the intact, conscious rat actually suffer from this type of diarrhoea? Apart from the very real difficulty of actually defining what is meant by diarrhoea in an experimental animal, it is generally acknowledged by experimentalists that it is difficult to induce secretory diarrhoea in conscious intact rats. Yet all who have worked with rat colonies know that individual rats can show brown, fluid like staining of the fur around the anus which is attributed to very fluid faeces (diarrhoea ?). In the Sheffield colony, we found an incidence of this staining in the fed rats of approximately $7 \%(30 / 426)$ while the incidence was more than doubled in the 3 day starved animals $(88 / 519=17 \%)$, but obviously we have no proof that such staining directly equates with an increased incidence of diarrhoea. A recent study, published at present only in abstract form by Fondacaro and his coworkers, ${ }^{+1}$ offers an explanation as to why the intact, conscious rat is so resistant to the induction of secretory diarrhoea. They report that after dosing rats with oral cholera toxin, the excess fluid secreted by the small bowel was retained in the caecum which only allowed fluid to enter the colon at a rate that did not exceed its absorptive capacity. If the rats were caecectomised and then dosed with the cholera toxin, secretory diarrhoea could be induced with consistent results. The caecum of rats is known to be able to hold large amounts of fluid, ${ }^{+2}$ indeed one basic characteristic of the germ free or pseudogerm free rat is its greatly enlarged, fluid filled caecum ${ }^{+2+3}$ but there is relatively mild or little diarrhoea. We hope to undertake experiments with caecectomised rats to see whether starvation induces a greater 
incidence of a 'diarrhoeal' state than in the caecectomised fed controls.

In the introduction to this study we mentioned that the diarrhoea of famine and malnutrition is often ascribed to infectious agents despite numerous studies reporting little or no obvious bacterial pathogens. ${ }^{10-13}$ Even if bacterial toxins are a factor in the diarrhoeal equation, however, our recent findings that the jejunum and ileum of starved and malnourished rats hypersecrete in response to challenge by Escherichia coli $\mathrm{STa}$ toxin $^{\text {t4 }}$ and Staphylococcus aureus enterotoxin $\mathrm{B}^{\text {t5 }}$ indicate that starvation and malnourishment create intestinal secretory hypersensitivity, not only to secretagogues but also to bacterial enterotoxins.

We conclude that progressive starvation (after 24 hours) in the rat induces a secretory hypersensitivity of the jejunum to a variety of secretagogues (including bacterial toxins) that can be observed in vivo as increased fluid and chloride movement into the lumen and in vitro as increased electrogenic chloride secretion. These observations suggest possible mechanisms that may be operating in human small intestine in relation to the diarrhoea of starvation and malnutrition.

A further paper ${ }^{46}$ describing the effects of progressive starvation on the secretory activity of the rat ileum when measured in vivo and in vitro will be published in a future issue.

A Young is supported by a Sheffield University Research Fellowship. Financial support given by the British Digestive Foundation.

1 Levin RJ. The intestinal absorption of some essential and nonessential amino acids in fed and fasting rats. Life Sci 1970; 9 61-8.

2 Debnam ES, Levin RJ. Effects of fasting and semistarvation on the kinetics of active and passive sugar absorption across on the kinetics of active and passive sugar absorption across
the small intestine in vivo. F P hysiol Lond 1975; 252: 681700 .

3 Levin RJ, Mitchell MA. Intestinal adaptations to fasting - use of corrected kinetic parameters to assess responses of jejunal and ileal absorption in vivo. In: Robinson JW, Dowling RH Riecken E-O, eds. Mechanisms of intestinal adaptation. Falk Symposium Nos 30. Lancaster: MTP Press Limited, 1982 103-10

4 Levin RJ. Intestinal adaptation to dietary change as exemplified by dietary restriction studies. In: Batt RM, Lawrence $\mathrm{TJ}$, eds. Function and dysfunction of the small intestine. Liverpool: Liverpool University Press, 1984: 77-93.

5 Debnam ES, Thompson CS. The effect of fasting on the potential difference across the brush-border membrane of potential difference across the brush-border membrane of 449-56.

6 Steiner M, Farrish GCM, Gray SJ. Intestinal uptake of valine in calorie and protein deprivation. Am $\mathcal{F}$ Clin Nutr 1969; 22 871-7.

7 Adibi SA, Allen ER. Impaired jejunal absorption rates of essential amino acids induced by either dietary caloric or protein deprivation in man. Gastroenterology 1970; 59: 404 13

8 Vasquez JA, Morse EL, Adibi SA. Effect of starvation on amino acid and peptide transport and peptide hydrolysis in humans. Am F Physiol 1985; 249: 563-6.

9 Medical Research Council. Studies of undernutrition. Wuppertal 1946-49. Medical Research Council Special Report Series nos 275. London: HMSO, 1951:61-3.

10 Keys A, Brozek J, Henschel A, Mickelson O, Taylor HL. The biology of starvation vol 1. USA: University of Minnesota Press, 1950: 587-90

11 Helweg-Larsen P, Hoffmeyer $H$, Kieler J, Thaysen EH, Thaysen JH, Thygesen P, Wulff MH. Famine disease in German concentration camps: complications and sequels. Acta Med Scand 1952; 274 (suppl): 1-460.

12 Winnick M. Hunger disease - studies by fewish physicians in the Warsaw Ghetto. New York: John Wiley, 1979

13 Roediger WEW. Metabolic basis for starvation diarrhoea: implications for treatment. Lancet 1986; i: $1082-4$.

14 James WPT. Effects of protein-calorie malnutrition on intestinal absorption. Ann NY Acad Sci 1971; 176: 244-61

15 Fondacaro JD. Intestinal transport and diarrheal disease. Am f Physiol 1986; 250: 1-8.
16 Cooke $\mathrm{H}$. Neural and humoral regulation of small intestinal electrolye transport. In: Johnson LR, ed. Physiology of the gastrointestinal tract. New York: Raven Press, 1987: 1307gastroit

17 Donowitz M, Welsh MJ. Regulation of mammalian smal intestinal electrolyte secretion. In: Johnson LR, ed. Physiology of the gastrointestinal tract. New York: Raven Press, 1987: 1351-8.

18 Levin RJ, Young A. Electrogenic currents induced by secretagogues across jejuna from fed and fasted rats. $\mathcal{f}$ Physiol Lond 1985; 365: 109 .

19 Levin RJ, Young A. The effects of fasting upon rat jejunal secretion in vitro and in vivo. $\mathcal{F}$ Physiol Lond 1986; 378: 23.

20 Levin RJ, Young A. The influence of tyramine released endogenous noradrenergic stores upon electrogenic endogenous noradrenergic stores upon electrogenic
secretion in the starved isolated rat jejunum. $f$ Physiol Lond secretion in the

21 Young A, Levin RJ. The involvement of chloride ions in the hypersecretory response to differing levels of cholinergic stimulation in the starved rat jejunum. Proc Nutr Soc 1988 47: 8

22 Krebs HA, Henseleit $K$. Untersuchungen uber die Harnestoffbildung im Tierkorper. HoppeSeyl Z 1932; 210 33-66.

23 Thomas EM, Templeton D. Noradrenergic innervation of the villi of rat jejunum. 7 Auton Nerv Syst 1981; 3: 25-9.

24 Tapper EJ, Bloom AS, Lewand DL. Endogenous norepinephrine release induced by tyramine modulates intestinal ion transport. Am f Physiol 1981; 241: 264-9.

25 Strombeck DR. The production of intestinal fluid by cholera toxin in the rat. Proc Soc Exp Biol Med 1972; 140:297-303.

26 Theodorsson-Nordheim E. Kruskal-Wallis test: BASIC computer program to perform nonparametric one-way analysis of variance and multiple comparisons on ranks of independent samples. Comput Methods Programs Biomed 1986; 23: 57-62.

27 Stevens-Hooper C, Blair M. The effect of starvation on epithelial renewal in the rat duodenum. Exp Cell Res 1958; 14: 175-81

28 Brown HO, Levine ML, Lipkin M. Inhibition of intestinal epithelial cell renewal and migration induced by starvation. Am 7 Physiol 1963; 205: 868-72.

29 Hopper AF, Wannemacher RW, McGovern PA. Cell population changes in intestinal epithelium of rat following starvation changes in intestinal epithelium of rat following starva-
tion and protein-depletion. Proc Soc Exp Biol Med 1968; tion and pro

30 Smith MW. Expression of digestive and absorptive function in differentiating enterocytes. Ann Rev Physiol 1985; 47: 24760

31 Thompson CS, Debnam ES. Starvation-induced changes in the autoradiographic localisation of valine uptake by rat small intestine. Experientia 1986; 42: 945-8.

32 Bolton JE, Field M. Ca ionophore-stimulated ion secretion in rabbit ileal mucosa: relation to actions of cyclic 3',5'AMP and carbamylcholine. 7 Membr Biol 1977; 35: 159-73.

33 Donowitz M, Asarkof N, Pike G. Calcium dependence of serotonin-induced changes in rabbit ileal electrolyte transport. 7 Clin Invest 1980; 66: 341-53.

34 Hardcastle J, Hardcastle PT. Membrane permeability change in intestinal secretion. Med Sci Res 1987; 15: 471-3.

35 Wahawisan R, Wallace LJ, Gaginella TS. Muscarinic receptors on rat ileal villus and crypt cells. $\mathcal{F}$ Pharm receptors on rat ileal vill
Pharmacol 1986; $38: 150-3$.

36 Lawson LD, Powell DW. Prostaglandins and leukotriene release by rabbit ileal components [Abstract]. Gastroenterology 1985; 88: 1467.

37 Martens H, Tobey NA, Rollin RE, Berschneider HM, Powel DW. Role of arachidonic acid metabolism in the stimulosecretion coupling of intestinal secretion [Abstract]. Gastroenterology 1985; 88: 1490.

38 Young JB, Landsberg L. Suppression of the sympathetic nervous system during fasting. Science $1977 ; 196$ : 1473-5.

39 Hubel KA. Intestinal ion transport: effect of norepinephrine, pilocarpine and atropine. Am f Physiol 1976; 231: 252-7.

40 Field M, Sheerin HE, Henderson A, Smith PL. Catechola mine effects on cyclic AMP levels and ion secretion in rabbit mine effects on cyclic AMP levels and ion sect

41 Fondacaro JD, Kolpak DC Burnham DH, McCafferty GP. Cecectomized rat: a model of experimental diarrhoea in conscious animals [Abstract]. Gastroenterology 1988; 94 A132.

42 Worstmann BS, Reddy BS, Bruckner-Kardoss E, Gordon HA, Singh B. Causes and possible consequences of cecal enlargement in germfree rats. In: Heneghan JB, ed. Germ free research-biological effect of gnotobiotic environments. New York: Academic Press, 1973: 261-9.

43 Gordon HA, Worstman BS. Chronic mild diarrhoea in germ free rodents: a model portraying host-flora synergism. In: Heneghan JB, ed. Germ free research - biological effect of Heneghan JB, ed. Germ free research - biological effect of
gnotobiotic environments. New York: Academic Press, 1973. gnotobiotic

44 Young A, Pereira MMC, Warren MA, Levin RJ. Hypersecre tion associated with the action of Escherichia coli STa
enterotoxin on the jejunum and ileum from starved and enterotoxin on the jejunum and ileum from starved and
chronically undernourished rats. Med Sci Res 1988; 16:

45 Young A, Nzegwu H, Levin RJ. Hypersecretion induced by Staphylococcus aureus enterotoxin B in the rat intestine. [Abstract] Gut 1988; 29: 1467A.

46 Young A, Levin RJ. The diarrhoea of famine and malnutrition - investigations using a rat model. ii - Ileal hypersecretion induced by starvation. Gut 1989. (In press). 